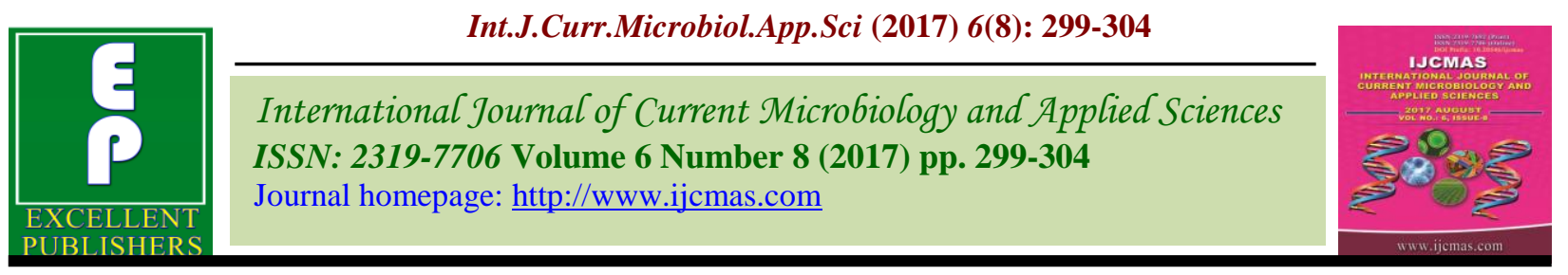

Original Research Article

https://doi.org/10.20546/ijcmas.2017.608.040

\title{
Effect of Spacing and Training on Growth and Yield of Polyhouse Grown Cucumber (Cucumis sativus L.)
}

\author{
Vikram Kumar Kapuriya*, K.D. Ameta, Suresh Kumar Teli, Akshay Chittora, \\ Suman Gathala and Satveer Yadav
}

\author{
Department of Horticulture, Rajasthan College of Agriculture, MPUA\&T, Udaipur, \\ Rajasthan 313001, India \\ *Corresponding author
}

\begin{tabular}{|c|c|}
\hline & A B S T R A C T \\
\hline & The present investigation was conducted during 2015-2016 at Hi-Tech Horticulture Unit, \\
\hline Keywords & $\begin{array}{l}\text { Department of Horticulture, Rajasthan College of Agriculture, Udaipur to study the effect } \\
\text { of different levels of spacing and training on growth and yield of cucumber under }\end{array}$ \\
\hline Cucun & polyhouse. The experiment was laid out following factorial completely randomized design \\
\hline Growth and & $\begin{array}{l}\text { (CRD) with three replications. The experiment was comprising of total twelve treatment } \\
\text { combinations of four level of spacing viz. } 45 \times 20 \mathrm{~cm}\left(\mathrm{~S}_{1}\right), 45 \times 30 \mathrm{~cm}\left(\mathrm{~S}_{2}\right), 45 \times 45 \mathrm{~cm}\left(\mathrm{~S}_{3}\right)\end{array}$ \\
\hline $\begin{array}{l}\text { Yield, Spacing, } \\
\text { Training }\end{array}$ & and $45 \times 60 \mathrm{~cm}\left(\mathrm{~S}_{4}\right)$ with three level of training viz. $T_{1}$ (removal of all branches up to $45 \mathrm{~cm}$ \\
\hline Article Info & was best in regards to vegetative and yield attributing traits. The maximum numbers of \\
\hline $\begin{array}{l}\text { Accepted: } \\
\text { 04 June } 2017 \\
\text { Available Online: } \\
10 \text { August } 2017\end{array}$ & $\begin{array}{l}\text { fruit per vine }(40.19) \text {, fruit weight }(119.69 \mathrm{~g}) \text {, yield per vine }(4.74 \mathrm{~kg}) \text { were recorded in } \mathrm{S}_{4} \text {. } \\
\text { Among the treatments of training, } \mathrm{T}_{1} \text { was superior resulting in maximum numbers of fruit } \\
\text { per vine }(38.17) \text {, fruit weight }(118.04 \mathrm{~g}) \text { and yield per } \mathrm{m}^{2}(17.71 \mathrm{~kg}) \text {. Maximum total yield } \\
\text { per vine }(4.97 \mathrm{~kg}) \text { was recorded in treatment combination } \mathrm{S}_{4} \mathrm{~T}_{3}(45 \times 60 \mathrm{~cm} \text { and up to } 135 \\
\mathrm{cm} \text { stem height). The highest net return (Rs. } 41405.2 \text { per } 1000 \text { square meter }) \text { and benefit: }\end{array}$ \\
\hline & D a tin $(100)$ \\
\hline
\end{tabular}

\section{Introduction}

Cucumber (Cucumis sativus L.) belonging to family Cucurbitaceae is a warm season vegetable, grown throughout the world under tropical and subtropical conditions. It is said to be the native of northern India (Pursglove, 1969). Cucumber is commonly a monoecious annual (one can encounter with androecious, gynoecious, hermaphrodite and andromonoecious sex types also), trailing or climbing vine (Bailey, 1969).

Cucumber is a highly cross pollinated crop and preferring warm weather and bright light for its better growth and development. However it can be grown in both summer and rainy season, but it can't tolerate cold injury.

Production of cucumber in India is mainly restricted to open field cultivation. Nevertheless, biotic and abiotic stresses are the main factor responsible for low yield and poor quality under open field cultivation particularly during rainy season crop. The protected vegetable cultivation technology can be utilized for year round production of high value quality vegetable crops, with high 
yield. Increased harvesting efficiency and greater yields, improved pest management, straighter fruits and more number of plants per acre due to closer rows are major advantages of adequate spacing and training; these are of vital importance for healthy and luxuriant growth of crop plants.

Greenhouse production technology of cucumber emphasizes the need for proper density in order to boost up the production per unit area by utilizing the available space and nutrients applied. There is need to assess the optimum plant density for its cultivation in polyhouses in various regions. An appropriate training system will not only facilitate better management and uniform light to the plants but also permit closer planting, early ripening of fruits, higher yield of larger sized fruits and higher yield of good quality seeds (Lal et al., 2014). Training methods vary with different growth habits of cucumber cultivars and for different plant densities. Plant density and shoot pruning contribute to marketable yield in the various ways such as plant's ability to obtain the sun light needed for growth and adequate air movement around the plant to reduce risk of fungus and insect problems. Manipulation of canopy architecture through pruning and training together with appropriate spatial arrangements has been identified as key management practices for getting maximum marketable yields from greenhouse crops (Premalatha et al., 2006).

Therefore, keeping above mentioned facts in view the present study was carried out to study the effect of different levels of spacing and training on growth and yield of cucumber under polyhouse.

\section{Materials and Methods}

The present investigation was conducted during 2015-2016 at Hi-Tech Horticulture Unit, Department of Horticulture, Rajasthan
College of Agriculture, Udaipur. The size of the polyhouse was $28 \mathrm{~m} \times 32 \mathrm{~m}$ (896 sq.m) covered with aluminate sheet and ultra violet stabilized low density polyethylene sheet having 200 micron thickness. The experiment was comprising of total twelve treatment combinations of four level of spacing viz. $45 \times 20 \mathrm{~cm}\left(\mathrm{~S}_{1}\right), 45 \times 30 \mathrm{~cm}\left(\mathrm{~S}_{2}\right), 45 \times 45 \mathrm{~cm}\left(\mathrm{~S}_{3}\right)$ and $45 \times 60 \mathrm{~cm}\left(\mathrm{~S}_{4}\right)$ with three level of training viz. $\mathrm{T}_{1}$ (removal of all branches up to $45 \mathrm{~cm}$ stem height), $\mathrm{T}_{2}$ (up to $90 \mathrm{~cm}$ stem height) and $\mathrm{T}_{3}$ (up to $135 \mathrm{~cm}$ stem height). The experiment was laid out following factorial completely randomized design (CRD) with three replications. Observations were recorded for fifteen different characteristics related to vegetative, yield and quality attributing traits. These observations were vine length $(\mathrm{cm})$, number of branches per vine, leaf area $\left(\mathrm{cm}^{2}\right)$, days to flowering, days to first harvest, number of fruits per vine, fruit weight $(\mathrm{g})$, fruit length $(\mathrm{cm})$, fruit volume (cc), fruit diameter $(\mathrm{cm})$, yield per vine $(\mathrm{kg})$, yield per square meter $(\mathrm{kg})$, specific gravity $(\mathrm{g} / \mathrm{cc})$, TSS $\left({ }^{\circ} \mathrm{B}\right)$, moisture content $(\%)$. The economics of different treatments were determined on the basis of prevailing market price of inputs and produce. The data recorded for various characters were subjected to statistical analysis using analysis of variance (ANOVA) under factorial CRD and interpretations of the data were carried out in accordance to Panse and Sukhatme (1985).

\section{Results and Discussion}

The data pertaining to various yield and yield contributing traits used for evaluation of the treatments were statistically analyzed to test their significance and results of these data have been given in tables 1 and 2 .

Results showed that maximum vine length $(325.19 \mathrm{~cm})$ was recorded in $\mathrm{S}_{4}(45 \times 60 \mathrm{~cm})$ while $\mathrm{T}_{3}$ (removal of all branches up to 135 
$\mathrm{cm}$ stem height) resulted in maximum vine length $(315.23 \mathrm{~cm})$. Interaction effects of spacing and training showed non-significant effect on vine length.

Results revealed that the effects of various levels of spacing and training were significant on number of branches per vine of cucumber. Maximum number of branches per vine $(12.54 \mathrm{~cm})$ was recorded in $\mathrm{S}_{4}(45 \times 60 \mathrm{~cm})$. Maximum number of branches per vine (12.97) was exhibited by $\mathrm{T}_{1}$ (removal of all branches up to $45 \mathrm{~cm}$ stem height).

Further, results revealed that maximum number of branches per vine (13.87) was recorded in $\mathrm{S}_{4} \mathrm{~T}_{1}(45 \times 60 \mathrm{~cm}$ and up to $45 \mathrm{~cm}$ height) whereas minimum (10.30) in $\mathrm{S}_{1} \mathrm{~T}_{3}(45$ $\times 20 \mathrm{~cm}$ and up to $135 \mathrm{~cm}$ height) treatment combination. Plants at widest spacing $(45 \mathrm{x}$ $60 \mathrm{~cm}$ ) resulted in maximum vine length and number of branches per vine than closer spacing. This may be due to the availability of more space for the plants. Significant linear increase of main vine length and number of branches per vine were also reported with increased spacing by Ban et al., (2006) in melon and Ara et al., (2007) in tomato. A perusal data revealed that the leaf area was significantly influenced by various levels of spacing and training. Data indicated that maximum value of leaf area was observed in in $\mathrm{S}_{4}\left(442.84 \mathrm{~cm}^{2}\right)$ treatment. Maximum leaf area $\left(435.49 \mathrm{~cm}^{2}\right)$ was recorded in $\mathrm{T}_{3}$ (up to $135 \mathrm{~cm}$ stem height). Results showed that maximum leaf area $\left(445.47 \mathrm{~cm}^{2}\right)$ was reported in $\mathrm{S}_{4} \mathrm{~T}_{1}(45 \times 60 \mathrm{~cm}$ and $45 \mathrm{~cm}$ height $)$ as compared to minimum $\left(425.87 \mathrm{~cm}^{2}\right)$ in $\mathrm{S}_{1} \mathrm{~T}_{1}$ $(45 \times 20 \mathrm{~cm}$ and $135 \mathrm{~cm}$ height $)$ treatment combination.

The data (Tables 1 and 2) indicated that the days to flowering of cucumber were significantly influenced by various levels of spacing and training. The minimum days taken for flowering (30.80) were noticed in the treatment $\mathrm{S}_{4}(45 \times 60 \mathrm{~cm})$. On other hand, minimum days for flowering (31.98) were taken in treatment $T_{1}$ (up to $135 \mathrm{~cm}$ stems height). Further, results showed that minimum days for flowering (30.17) were taken by $\mathrm{S}_{4} \mathrm{~T}_{1}$ $(45 \times 60 \mathrm{~cm}$ and $45 \mathrm{~cm}$ height) whereas maximum days for flowering (33.70) were taken by treatment combination $\mathrm{S}_{1} \mathrm{~T}_{1}(45 \times 20$ $\mathrm{cm}$ and $45 \mathrm{~cm}$ height). It is explicit from data that the days to first harvesting of cucumber was not significantly influenced by various levels of spacing while it was significantly influenced by various levels of training. Minimum days for harvesting (37.98) were taken by treatment $\mathrm{T}_{1}$ (up to $45 \mathrm{~cm}$ stem height). Interaction effects of spacing and training had significant influence on days to first harvesting. Minimum days taken for first harvesting (36.17) were observed for $\mathrm{S}_{4} \mathrm{~T}_{1}(45$ $\times 60 \mathrm{~cm}$ and up to $45 \mathrm{~cm}$ height) whereas maximum number of days (39.70) for first harvesting was observed in $\mathrm{S}_{1} \mathrm{~T}_{1}(45 \times 20 \mathrm{~cm}$ and up to $45 \mathrm{~cm}$ height).

Results indicated that the number of fruit per vine was significantly influenced by various levels of spacing and training. The maximum number of fruits per vine (40.19) was recorded in spacing $S_{4}(45 \times 60 \mathrm{~cm})$ followed by $S_{3}(37.17), S_{2}(35.49)$ whereas $T_{1}$ resulted in maximum number of fruits per vine (38.17). There was non-significant influence of interaction of spacing and training on number of fruits per vine. Fruit weight was significantly influenced by various levels of spacing and training. Results showed that maximum fruit weight $(119.69 \mathrm{~g})$ was observed for treatment $\mathrm{S}_{4}(45 \times 60 \mathrm{~cm})$. Maximum fruit weight (118.04 $\mathrm{g}$ ) was found in the first level of training $\mathrm{T}_{1}$ (up to $45 \mathrm{~cm}$ stem height). Data clearly indicated nonsignificant influence of interaction effect of spacing and training on fruit weight. The maximum number of fruits per vine and fruit weight were reported for widest spacing i.e. treatment $\mathrm{S}_{4}(45 \times 60 \mathrm{~cm})$, this might be due to more fruit set and more photosynthesis as it produce more vine length at wider spacing. 
Table.1 Effect of spacing and training on vegetative, yield and quality attributes of polyhouse grown cucumber

\begin{tabular}{|c|c|c|c|c|c|c|c|c|c|c|c|c|c|c|c|}
\hline Treatment & $\begin{array}{c}\text { Vine } \\
\text { length } \\
(\mathrm{cm})\end{array}$ & $\begin{array}{c}\text { Number } \\
\text { of } \\
\text { branche } \\
\text { s per } \\
\text { vine }\end{array}$ & $\begin{array}{l}\text { Leaf } \\
\text { area } \\
\left(\mathrm{cm}^{2}\right)\end{array}$ & $\begin{array}{c}\text { Days to } \\
\text { flowerin } \\
\mathrm{g}\end{array}$ & $\begin{array}{c}\begin{array}{c}\text { Days to } \\
\text { first } \\
\text { harvest }\end{array}\end{array}$ & $\begin{array}{l}\text { Number } \\
\text { of fruits } \\
\text { per vine }\end{array}$ & $\begin{array}{c}\text { Fruit } \\
\text { weight } \\
\text { (g) }\end{array}$ & $\begin{array}{c}\text { Fruit } \\
\text { length } \\
\text { (cm) }\end{array}$ & $\begin{array}{c}\text { Fruit } \\
\text { diamete } \\
\mathbf{r} \\
(\mathrm{cm})\end{array}$ & $\begin{array}{c}\text { Total } \\
\text { yield } \\
\text { per vine } \\
\text { (kg) }\end{array}$ & $\begin{array}{c}\text { Yield } \\
\text { per } \mathrm{m}^{2}\end{array}$ & $\begin{array}{c}\text { Moistur } \\
\text { e } \\
\text { content } \\
(\%)\end{array}$ & $\begin{array}{c}\text { Total } \\
\text { soluble } \\
\text { solids } \\
\left({ }^{0} \text { Brix }\right)\end{array}$ & $\begin{array}{c}\text { Fruit } \\
\text { volume } \\
\text { (cc) }\end{array}$ & $\begin{array}{c}\text { Specific } \\
\text { gravity } \\
(\mathrm{g} / \mathrm{cc})\end{array}$ \\
\hline \multicolumn{16}{|l|}{ Spacing (S) } \\
\hline $\mathrm{S}_{1}(45 \times 20 \mathrm{~cm})$ & 306.67 & 11.63 & 426.26 & 32.91 & 38.69 & 33.82 & 114.19 & 15.20 & 2.44 & 2.33 & 20.03 & 92.00 & 4.03 & 125.31 & 0.91 \\
\hline $\mathrm{S}_{2}(45 \times 30 \mathrm{~cm})$ & 312.67 & 12.19 & 430.83 & 32.62 & 38.73 & 35.49 & 115.88 & 16.51 & 2.60 & 2.61 & 17.16 & 92.67 & 3.66 & 125.78 & 0.92 \\
\hline $\mathrm{S}_{3}(45 \times 45 \mathrm{~cm})$ & 317.64 & 12.27 & 435.57 & 32.48 & 38.48 & 37.17 & 116.43 & 17.78 & 3.01 & 3.57 & 15.69 & 93.60 & 3.48 & 126.30 & 0.92 \\
\hline $\mathrm{S}_{4}(45 \times 60 \mathrm{~cm})$ & 325.19 & 12.54 & 442.84 & 30.80 & 36.80 & 40.19 & 119.69 & 18.33 & 3.30 & 4.74 & 15.40 & 94.59 & 3.32 & 126.92 & 0.94 \\
\hline $\mathrm{SEm} \pm$ & 0.848 & 0.153 & 0.234 & 0.109 & 0.160 & 0.230 & 0.250 & 0.128 & 0.054 & 0.042 & 0.148 & 0.109 & 0.026 & 0.124 & 0.002 \\
\hline $\mathrm{CD}$ at $5 \%$ & 1.413 & 0.446 & 0.684 & 0.319 & NS & 0.673 & 0.730 & 0.374 & NS & 0.123 & 0.432 & 0.319 & 0.075 & 0.361 & 0.005 \\
\hline \multicolumn{16}{|l|}{ Training (T) } \\
\hline $\mathrm{T}_{1}$ & 314.83 & 12.97 & 432.38 & 31.98 & 37.98 & 38.17 & 118.04 & 17.32 & 2.93 & 3.07 & 17.71 & 93.70 & 3.75 & 127.34 & 0.93 \\
\hline $\mathrm{T}_{2}$ & 315.23 & 12.34 & 433.75 & 32.08 & 38.08 & 36.58 & 116.14 & 16.89 & 2.86 & 3.37 & 16.98 & 93.30 & 3.62 & 125.85 & 0.92 \\
\hline $\mathrm{T}_{3}$ & 316.57 & 11.17 & 435.49 & 32.54 & 38.46 & 35.25 & 115.46 & 16.66 & 2.74 & 3.50 & 16.52 & 92.64 & 3.50 & 125.04 & 0.92 \\
\hline SEm \pm & 0.419 & 0.132 & 0.203 & 0.095 & 0.138 & 0.200 & 0.216 & 0.111 & 0.047 & 0.036 & 0.128 & 0.095 & 0.022 & 0.107 & 0.002 \\
\hline $\mathrm{CD}$ at $5 \%$ & 1.224 & 0.386 & 0.592 & 0.276 & 0.404 & 0.583 & 0.632 & 0.324 & 0.137 & 0.106 & 0.374 & 0.277 & 0.065 & 0.312 & 0.005 \\
\hline
\end{tabular}

Table.2 Interaction effects of spacing and training on vegetative, yield, quality and economics of polyhouse grown cucumber

\begin{tabular}{|c|c|c|c|c|c|c|c|c|c|c|c|c|c|c|c|c|c|}
\hline Treatment & $\begin{array}{c}\text { Vine } \\
\text { length } \\
\text { (cm) }\end{array}$ & $\begin{array}{c}\text { Numb } \\
\text { er of } \\
\text { branch } \\
\text { es per } \\
\text { vine }\end{array}$ & $\begin{array}{l}\text { Leaf } \\
\text { area } \\
\left(\mathrm{cm}^{2}\right)\end{array}$ & $\begin{array}{c}\text { Days to } \\
\text { floweri } \\
\text { ng }\end{array}$ & $\begin{array}{c}\text { Days } \\
\text { to first } \\
\text { harves } \\
t\end{array}$ & $\begin{array}{c}\text { Numb } \\
\text { er of } \\
\text { fruits } \\
\text { per } \\
\text { vine }\end{array}$ & $\begin{array}{c}\text { Fruit } \\
\text { weight } \\
\text { (g) }\end{array}$ & $\begin{array}{c}\text { Fruit } \\
\text { length } \\
\text { (cm) }\end{array}$ & $\begin{array}{c}\text { Fruit } \\
\text { diamet } \\
\text { er } \\
(\mathrm{cm})\end{array}$ & $\begin{array}{l}\text { Total } \\
\text { yield } \\
\text { per } \\
\text { vine } \\
(\mathrm{kg})\end{array}$ & $\begin{array}{l}\text { Yield } \\
\text { per } \mathrm{m}^{2}\end{array}$ & $\begin{array}{c}\text { Moistu } \\
\text { re } \\
\text { conten } \\
\mathbf{t}(\%)\end{array}$ & $\begin{array}{c}\text { Total } \\
\text { soluble } \\
\text { solids } \\
\left({ }^{\circ} \text { Brix }\right)\end{array}$ & $\begin{array}{c}\text { Fruit } \\
\text { volum } \\
\text { e (cc) }\end{array}$ & $\begin{array}{c}\text { Specifi } \\
\text { c } \\
\text { gravity } \\
(\mathrm{g} / \mathrm{cc})\end{array}$ & $\begin{array}{c}\text { Net } \\
\text { return } \\
\text { per } 1000 \\
\mathbf{m}^{2}\end{array}$ & $\begin{array}{l}\mathrm{B}: \mathrm{C} \\
\text { ratio }\end{array}$ \\
\hline $\mathrm{S}_{1} \mathrm{~T}_{1}$ & 306.13 & 12.50 & 425.87 & 33.70 & 39.70 & 35.13 & 115.20 & 15.80 & 2.20 & 2.17 & 20.90 & 92.63 & 4.33 & 126.67 & 0.91 & 41405.2 & 1.60 \\
\hline $\mathrm{S}_{1} \mathrm{~T}_{2}$ & 306.23 & 12.40 & 426.17 & 32.03 & 38.03 & 33.70 & 113.83 & 15.03 & 2.60 & 2.35 & 19.87 & 92.17 & 4.00 & 125.13 & 0.91 & 37688.00 & 1.41 \\
\hline $\mathrm{S}_{1} \mathrm{~T}_{3}$ & 307.63 & 10.30 & 426.73 & 33.00 & 38.33 & 32.63 & 113.53 & 14.77 & 2.23 & 2.46 & 19.33 & 91.20 & 3.77 & 124.13 & 0.91 & 35580.00 & 1.31 \\
\hline $\mathrm{S}_{2} \mathrm{~T}_{1}$ & 312.33 & 12.40 & 429.37 & 32.37 & 38.37 & 37.33 & 117.23 & 16.90 & 2.73 & 2.50 & 17.86 & 93.40 & 3.74 & 127.17 & 0.92 & 34362.60 & 1.46 \\
\hline $\mathrm{S}_{2} \mathrm{~T}_{2}$ & 312.80 & 12.30 & 430.67 & 32.60 & 38.60 & 35.27 & 115.57 & 16.53 & 2.43 & 2.59 & 17.20 & 92.67 & 3.65 & 127.67 & 0.92 & 31855.00 & 1.33 \\
\hline $\mathrm{S}_{2} \mathrm{~T}_{3}$ & 312.87 & 11.87 & 432.47 & 32.90 & 39.23 & 33.87 & 114.83 & 16.10 & 2.63 & 2.75 & 16.43 & 91.63 & 3.57 & 124.50 & 0.92 & 28991.00 & 1.20 \\
\hline $\mathrm{S}_{3} \mathrm{~T}_{1}$ & 316.90 & 13.10 & 434.23 & 31.70 & 37.70 & 38.43 & 118.73 & 17.97 & 3.00 & 3.27 & 15.90 & 93.87 & 3.52 & 127.53 & 0.93 & 28991.00 & 1.33 \\
\hline $\mathrm{S}_{3} \mathrm{~T}_{2}$ & 317.60 & 12.50 & 435.17 & 32.33 & 38.33 & 37.37 & 115.77 & 17.80 & 3.17 & 3.60 & 15.60 & 93.70 & 3.49 & 126.03 & 0.92 & 28064.00 & 1.25 \\
\hline $\mathrm{S}_{3} \mathrm{~T}_{3}$ & 318.43 & 11.20 & 437.30 & 33.40 & 39.40 & 35.70 & 114.80 & 17.57 & 2.87 & 3.83 & 15.57 & 93.23 & 3.43 & 125.33 & 0.92 & 28064.00 & 1.21 \\
\hline $\mathrm{S}_{4} \mathrm{~T}_{1}$ & 323.93 & 13.87 & 440.07 & 30.17 & 36.17 & 41.77 & 121.00 & 18.60 & 3.47 & 4.33 & 16.20 & 94.90 & 3.40 & 128.00 & 0.95 & 32308.00 & 1.57 \\
\hline $\mathrm{S}_{4} \mathrm{~T}_{2}$ & 324.30 & 12.47 & 443.00 & 31.37 & 37.37 & 40.00 & 119.40 & 18.20 & 3.23 & 4.93 & 15.27 & 94.67 & 3.35 & 126.57 & 0.94 & 28904.00 & 1.41 \\
\hline $\mathrm{S}_{4} \mathrm{~T}_{3}$ & 327.33 & 11.30 & 445.47 & 30.87 & 36.87 & 38.80 & 118.67 & 18.20 & 3.20 & 4.97 & 14.73 & 94.20 & 3.21 & 126.20 & 0.94 & 26796.00 & 1.28 \\
\hline $\mathrm{SEm} \pm$ & 0.839 & 0.265 & 0.406 & 0.189 & 0.277 & 0.399 & 0.433 & 0.22 & 0.94 & 0.073 & 0.256 & 0.190 & 0.045 & 0.214 & 0.003 & 830.3835 & 0.0349 \\
\hline $\mathrm{CD}$ at $5 \%$ & NS & 0.1722 & 1.185 & 0.552 & 0.807 & NS & NS & NS & NS & 0.2128 & NS & NS & 0.130 & NS & NS & 2423.7179 & 0.1018 \\
\hline
\end{tabular}


The similar findings of increase average fruit weight and number of fruits per vine with wider spacing were also reported by Mantur et al., (2007) and Ameta et al., (2014) in capsicum.

Fruit length of cucumber was significantly influenced by various levels of spacing. Results showed that highest fruit length $(18.33 \mathrm{~cm})$ was recorded in widest level of spacing $\mathrm{S}_{4}(45 \times 60$ $\mathrm{cm})$ followed by $\mathrm{S}_{3}(17.78 \mathrm{~cm})$. Mamnoie and Dolatkhahi (2013) and Jaffer and Wahid (2014) also recorded more fruit length at wider spacing. Maximum fruit length $(17.32 \mathrm{~cm})$ was observed in $\mathrm{T}_{1}$ (up to $45 \mathrm{~cm}$ stem height) followed by $\mathrm{T}_{2}(16.89 \mathrm{~cm})$. Results revealed that interaction of spacing and training exhibited non-significant effects on fruit length. The data indicated that the fruit diameter of cucumber was significantly influenced by various level of training. Maximum fruit diameter $(2.93 \mathrm{~cm})$ was observed in treatment $T_{1}$ (up to $45 \mathrm{~cm}$ stem height). Maximum fruit length, fruit diameter, fruit volume $(127.34 \mathrm{cc})$ and specific gravity $(0.93 \mathrm{~g} / \mathrm{cc})$ were reported in treatment of minimum pruning i.e. $\mathrm{T}_{1}$ (up to $45 \mathrm{~cm}$ stem height). This is in conformity with the findings of Muhammad and Singh (2007) while working with tomato. Interaction effects of spacing and training was non-significant on fruit diameter.

Various levels of spacing and training imparted significant influence on total yield per vine $(\mathrm{kg})$. Maximum total yield per vine $(4.74 \mathrm{~kg})$ was obtained for treatment $S_{4}(45 \times 60 \mathrm{~cm})$ while third level of training $\mathrm{T}_{3}$ (up to $135 \mathrm{~cm}$ stems height) resulted in the highest total yield per vine $(3.50 \mathrm{~kg})$. Similarly maximum total yield per vine $(4.97 \mathrm{~kg})$ was obtained in $\mathrm{S}_{4} \mathrm{~T}_{3}(45 \times 60$ $\mathrm{cm}$ and $135 \mathrm{~cm}$ height). It is evident from data that the total yield per $\mathrm{m}^{2}(\mathrm{~kg})$ of cucumber was significantly influenced by various levels of spacing and training. The maximum total yield per vine was recorded at widest spacing i.e. $\mathrm{S}_{4}$ $(45 \times 60 \mathrm{~cm})$ whereas least yield was recorded when plants were accommodated at closer spacing $(45 \times 20 \mathrm{~cm})$. These findings are in conformity with findings of Abubaker et al., (2010) in cucumber. The data showed that the highest total yield per $\mathrm{m}^{2}(20.03 \mathrm{~kg})$ was observed in treatment $S_{1}(45 \times 20 \mathrm{~cm})$ followed by $S_{2}(17.16 \mathrm{~kg})$. First level of training i.e. $\mathrm{T}_{1}$ (up to $45 \mathrm{~cm}$ stem height) exhibited maximum total yield per $\mathrm{m}^{2}(17.71 \mathrm{~kg})$ followed by $\mathrm{T}_{2}$ $(16.98 \mathrm{~kg})$. Interaction effects of spacing and training presented in table 2 showed nonsignificant effect on total yield per $\mathrm{m}^{2}(\mathrm{~kg})$. However, maximum total yield per $\mathrm{m}^{2}(20.90$ $\mathrm{kg})$ was observed for $\mathrm{S}_{1} \mathrm{~T}_{1}(45 \times 20 \mathrm{~cm}$ and 45 cm height).

It is explicit from data that the moisture content (\%) of cucumber was significantly influenced by various levels of spacing and training. maximum moisture content $(94.59 \%)$ was recorded for $\mathrm{S}_{4}(45 \times 60 \mathrm{~cm})$ while at other hand, maximum moisture content $(93.70 \%)$ was observed for treatment $\mathrm{T}_{1}$ (up to $45 \mathrm{~cm}$ stems height). A critical examination of data showed that interaction effects of spacing and training were non-significant on moisture content of fruit $(\%)$. Total soluble solids of cucumber were significantly influenced by various levels of spacing and training. Data showed that maximum total soluble solids $\left(4.03{ }^{\circ} \mathrm{B}\right)$ was recorded in treatment $S_{1}(45 \times 20 \mathrm{~cm})$ while at other hand, maximum total soluble solids (3.75 ${ }^{\circ} \mathrm{B}$ ) was recorded in treatment $\mathrm{T}_{1}$ (up to $45 \mathrm{~cm}$ stem height). Maximum TSS $\left(4.33{ }^{\circ} \mathrm{B}\right)$ was exhibited by treatment combination $\mathrm{S}_{1} \mathrm{~T}_{1}(45 \times$ $20 \mathrm{~cm}$ and $45 \mathrm{~cm}$ height).

It is explicit from data that the fruit volume (cc) of cucumber was significantly influenced by various levels of spacing and training. Maximum fruit volume $(126.92 \mathrm{cc})$ was reported in $S_{4}(45 \times 60 \mathrm{~cm})$ followed by $S_{3}$ (126.30 cc). First level of training $\mathrm{T}_{1}$ (up to 45 $\mathrm{cm}$ stem height) was reported to result maximum fruit volume $(127.34 \mathrm{cc})$. A critical review of data showed that interaction effects of spacing and training on fruit volume (cc) was non-significant. The data with regard to specific gravity of fruit was significantly influenced by various levels of spacing and training. Data showed that maximum specific gravity (0.94 $\mathrm{g} / \mathrm{cc})$ was exhibited in $\mathrm{S}_{4}(45 \times 60 \mathrm{~cm})$ while treatment $\mathrm{T}_{1}$ (up to $45 \mathrm{~cm}$ stems height) resulted maximum specific gravity $(0.93 \mathrm{~g} / \mathrm{cc})$. 
Interaction effects of spacing and training on specific gravity were non-significant during experimentation.

Economic evaluation of treatments revealed that maximum net returns (Rs. 41405.2 per 1000 square meter) and benefit:cost ratio (1.60) was recorded in the treatment combination $\mathrm{S}_{1} \mathrm{~T}_{1}$ (45x20 cm and up to $45 \mathrm{~cm}$ stem height) whereas, minimum net returns (Rs. 26796 per 1000 square meter) and $\mathrm{B}: \mathrm{C}$ ratio (1.28) was recorded in treatment combination $\mathrm{S}_{4} \mathrm{~T}_{3}(45 \times 60$ $\mathrm{cm}$ and up to 135 stem height).

On the basis of results obtained in the present investigation it was concluded that among the various treatment combinations, highest yield and benefit: cost ratio were recorded by treatment combination $\mathrm{S}_{1} \mathrm{~T}_{1}(45 \times 20 \mathrm{~cm}$ and up to $45 \mathrm{~cm}$ stem height). Based on above findings, $\mathrm{S}_{1} \mathrm{~T}_{1}$ was recommended for getting maximum yield.

\section{References}

Abubaker, S., Al-Zubi1, Y. and Aburayan, A. 2010. The influence of plant spacing on yield and fruit nitrate concentration in greenhouse cucumber (Cucumis sativus L.). Jordan J. Agric. Sci., 6(4): 527-533.

Ameta, K. D., Kaushik, R. A., Dubey, R. B. and Pareek, S. 2014. Effect of training and crop geometry on yield attributes and yield of polyhouse grown "Natasha" red capsicum. Int. J. Innovat. Hort., 3(1): 6770.

Ara, N., Bashar, M. K., Begum, S. and Kakon, S. S. 2007. Effect of spacing and stem pruning on the growth and yield of tomato. Int. J. Sustain. Crop Prod., 2(3): 35-39.

Bailey, L. H. 1969. Mannual of Cultivated Plants. Macmillan Company, New York.
Ban, D., Goreta, S. and Borosic, J. 2006. Plant spacing and cultivar affect melon growth and yield components. Sci. Hort., 109: 238-243.

Jaffer, A. and Wahid, F. 2014. Effect of row spacing on growth, yield and yield components of cucumber varieties. Science Letters, 2(1): 33-38.

Lal, M., Kanwar, H.S. and Kanwar, R. 2014. Impact of spacing and training on seed yield of capsicum, Capsicum annuum $\mathrm{L}$. under protected conditions. Int. J. Farm Sci., 4(3): 42-48.

Mamnoie, E. and Dolatkhahi, A. 2013. Plant spacing and cultivar affects yield components, qualitative traits and early ripening of tomato (Lycopersicon esculentum). Notulae Scientia Biologica, 5(4): 494-498.

Mantur, S. M. and Patil, S. R. Biradar, S.R., Patil, S.R. and Patil, D.R. 2007. Effect of plant geometry and nutrient source for capsicum under shade house during summer and kharif. Karnataka J. Agric. Sci., 21(1): 97-98.

Muhammad, A. and Singh, A. 2007. Yield of tomato as influenced by training and pruning in the Sudan savanna of Nigeria. J. Plant Sci., 2(3): 310-317.

Panse, V. G. and Sukhatme, P. V. 1985. Statistical Methods for Agricultural Workers. ICAR, New Delhi, pp. 145-155.

Premalatha, M.G.S., Wahundeniya, K.B., Weerakkody, W.A.P. and Wicramathunga, C.K. 2006. Plant training and spatial arrangement for yield improvements in greenhouse cucumber (Cucumis sativus L.) varieties. Trop. Agric. Res., 18: 346-357.

Pursglove, J. W. 1969. Tropical Crops Dicotyledons Longmans. Green and Corporation Limited London and Herlow.

\section{How to cite this article:}

Vikram Kumar Kapuriya, K.D. Ameta, Suresh Kumar Teli, Akshay Chittora, Suman Gathala and Satveer Yadav. 2017. Effect of Spacing and Training on Growth and Yield of Polyhouse Grown Cucumber (Cucumis sativus L.). Int.J.Curr.Microbiol.App.Sci. 6(8): 299-304. doi: https://doi.org/10.20546/ijcmas.2017.608.040 